\title{
On Social Reality behind the Absurdity of Barthelme's The Glass Mountain
}

\author{
Xiaohua Wen \\ School of Foreign Languages, Hangzhou Normal University, Hangzhou, China
}

\begin{abstract}
Donald Barthelme's The Glass Mountain is listed as one of the most representative postmodern fictions, but behind the absurdity lies social reality. This essay analyzes it in three different perspectives, i.e. structural, linguistic and narrative perspectives, finding that the fiction closely reflects the social facts, including the disorder of the capitalist system, people's spiritual conflicts and struggle for peace and order, and the abnormality and indifference between acquaintances, which simultaneously embodies the author's inner poignancy to the existing social reality of the age on the one hand, as well as his sincere wishes for the harmonious and natural social relationship on the other.
\end{abstract}

Index Terms - Barthelme, The Glass Mountain, absurdity, reality

\section{INTRODUCTION}

During the Second World War, America made a large fortune by offering the warring countries financial aids and in the meantime, the whole country enjoyed a great development in its material wealth. After the war, the USA and the USRR, the two greatest powers representing the two opposites from the West and the East, entered the period of the Cold War, lasting a quarter-century. In addition, America launched Korean War and Vietnam War, which influenced American people's attitude toward the wars greatly. More such influential historical events as the atomic bombings, the murdering of Martin Luther King and the assassination of President Kennedy took place in America, which, to a great extent, played an important role in influencing American people's spiritual life and their views of cultural values.

In 1960's, there emerged a type of "New Fiction" that seriously challenged and attempted to subvert the very foundation of the accepted concept of literature, and a decade later, the phenomenon of postmodernism became a matter of heated academic discussion (Yu, 2010). The Glass Mountain, written by Donald Barthelme, is regarded as one of the most representative postmodern fictions. This fiction is categorized into the Theater of Absurdity, but literature is a mirror of the times; therefore, it inevitably more or less reflects the social reality of the age.

\section{THE ABSURDITY OF THE FICTION}

The Glass Mountain was originally a traditional fairy tale included by Andrew Lang in his The Yellow Fairy Book. Barthelme's short story "The Glass Mountain" is a parody of the tale, with the direction of the story line and the setting being dramatically altered. The story goes: On a glass mountain grew a tree with golden apples. Anyone who picked a golden apple would be able to go into the golden castle where an enchanted princess lived. Many knights had tried and failed, because the castle was guarded by a fierce eagle. A brave lad killed a lynx and climbed with its claws attached to his feet and hands. When the eagle came to attack, he seized its feet and was carried up the rest of the way. He cut off its feet, landed on the apple tree, managed to go into the castle and rescued the princess. Finally, he married the princess and they lived happily ever after.

In Barthelme's short story of the same title, the glass mountain is in fact not a real mountain at all but a high office building located at the corner of Thirteenth Street and Eighth Avenue in America. Throughout the story, it is inserted with fragments of the fairy tale to make it look distracted, decentralized and disconnected not only in structure but also in logic and content. With the fairy tale as the background, no trace of anything heroic or romantic can be found, nor is a happy ending possible in this postmodern rewriting. By means of collage technique --- piecing together little fragments, and by numbering sentences, the author presented a picture of an absurd man doing absurd things in an absurd world.

\section{REALITY AND SOCIAL CRITICISM BEHIND THE ABSURDITY}

Postmodern fiction is understood by Gerhard Hoffmann (2005) as a very serious, sometimes desperate, but also playful attempt to cope with the accumulated dubieties, insecurities, vagaries and skepticisms of our time. Fredric Jameson, a famous scholar, calls Postmodernism "the cultural logic of late capitalism." (cited from Yu, 2010, p.115) Both of them make it clear the close relationship between postmodern literature and the existing society or reality.

A. Structural Perspective

Barthelme superficially narrates us readers a story about a modern man climbing comically a modern glass 
skyscraper, thinking about absurd things time and time again in the course of climbing. We may easily find the word games played by the fictionist, seemingly nonsense and discontinued at all.

1. The explicit ordering with numbers

Contrary to the traditional literary works, what impresses us readers at first glance is the numbering of the paragraphs, each of which is composed of only one sentence, with the shortest sentence consisting of only one single word and the longest one of 151 words including the source of literature in the brackets.

The arrangement of the hundred numbers gives an impression of a neat order and an ideal integration with the number of 100. Taking the discontinuity and illogic of the story into consideration, the numbering undoubtedly constructs an explicit conflict between the form and content, reflecting the controversy between the human expectation and the chaotic society and also the extreme irony to the social reality.

After World War II, science and technology developed quickly and economy boomed in America and as a result, American people were enjoying a wealthy material life. Entering the period of the Cold War, the USA made every effort to compete with the Soviet Union in nuclear weapons, spending an enormous amount of money on atomic race. At the same time America waged two invasive wars in Asia, forcing thousands of young American people to fight in the battlefields for a long time. Within the country, a series of social movements such as Civil Rights Movement, Women's Movement and Youth/Antiwar Movement emerged, demonstrating a great dissatisfaction with the present society and system. People began to feel skeptical about the state government and the existing moral criteria and subsequently started counter-culture movements, which unfolded the real picture of the 1960's in America, everything in a chaotic order. On the other hand, the numbering shows the artist's hope and dream of living a normal and orderly life.

2. The ending

The last four paragraphs serve the ending of the story. Here, the symbol turns out to be a beautiful princess, a huge discrepancy between the expectation and the experience, disenchanting the narrator's ideal and pursuit as well. The narrator seeks to escape from his ugly, hostile surroundings to the realm of art but what he finds is just more conventions and more clichés, which indicates the social reality that individual power is far from enough in the world to make reform probable.

The unexpected result in sentence 98 helps us to know that Barthelme as an artist himself, conscious of the struggles and the boredom of an ordinary man, tries to reflect this mood 'in new revitalized literary forms, with new methods such as verbal fragmentation and free association to break down the familiar sense of order and to stay on the surface refusing to explain the deep meanings' (McCaffery, 1982, p.101). The narrator's extreme disappointment and his strong determination to destroy the conventional symbol are made clear in the ending part by throwing the beautiful princess headfirst down the mountain, which behavior reflects profoundly the artist's actual removal of conventions.

What's most significant is the last paragraph, an inverted-order sentence guided by "Nor", containing three negative elements to end up the whole fiction with a definite subversion of the human expectation. The way the story ends shows that 'Barthelme tells us about the predicament of the artist, envied, hated and alienated from his society for having dedicated himself to his art --- a task as precarious and unrewarding as climbing a glass mountain' (Araz, 1999, p.88) in the story. In the meantime, this ending exhibits the narrator's ultimate disillusion of the social reality and the conventional narration as well.

\section{B. Linguistic Perspective}

Language is the essential part for readers to understand a piece of literary work. In "The Glass Mountain", Barthelme plays with the meanings of words, relying on poetic intuition to spark new connections of ideas buried in the expressions and conventional responses.

1. Transition between the past and the present tense

The majority of the short story uses the past tense form, describing the past happenings---my climbing the glass mountain. Excluding the direct speeches and the citations in the double quotation marks, it's found that the present tense form appears in sentences $2,13,14,15,16,17,18,19,27,44,45,46,47,48,58,59,62,67,80$ and 100 , twenty sentences in total among the hundred.

Writers generally use either the past tense or the present tense to tell a story, supposed to keep one tense form in conformity throughout the writing. Reading carefully the sentences using the present tense, we find they are related to some hard facts, for example, sentence 2 "The glass mountain stands at the corner of Thirteenth Street and Eighth Avenue." states the location of a real modern glass skyscraper; or to some hot issues prevailing in the society, such as sentences 58 "Does one climb a glass mountain, at considerable personal discomfort, simply to disenchant a symbol?" and 59 "Do today's stronger egos still need symbols?" to start an implied discussion with the climber himself or with the masses; or to some routines like sentences 62 "The best way to fail to climb the mountain is to be a knight in full armor---one whose horse's hoofs strike fiery sparks from the sides of the mountain." and 80 "The conventional means of attaining the castle are as follows..." to draw our readers' attention to the traditions or conventions; or to the final but permanent disillusionment as the last sentence shows us "100. Nor are eagles plausible, not at all, not for a moment."

The usage of the present tense in the fiction frequently alternated with the past tense usage leads to the association with the transition between the imagined world and the real world, i.e. the absurdity of the inner mind. The greater proportion of the past tense implies the larger amount of imagination, or illusion. In contrast, the present tense connotates the reality. The story begins with the past tense and ends with the present tense, reflecting the struggle or 
competition between imagination and reality, between expectation and un-expectation, between illusion and disillusion, and ultimately coming back to the real society to deny all the fictive world.

2. Lexical hints reflecting the real world

It's usually concluded that the postmodernist deals with the absurd or meaningless confusion of contemporary existence with a certain numbed or flippant indifference, favoring self-consciously depthless works of fabulation, pastiche, or aleatory disconnections. Following this thought, the postmodern fiction "The Glass Mountain" is fancied rather than realistic. However, such words and expressions as Thirteenth Street and Eighth Avenue (see sentence 2), the VWs and Valiants (see sentence 31), Anton Ehrenzweig (see sentence 56), M. Pompidou (see sentence 66), the Bandaids (see sentences 82, 84, 85, 86), John Masefield (see sentence 87) and the like, are all true marks for the real tangible world, reminding people of the reality as the larger background as compared with the conventional fairy tale. It's undoubted that we can feel and even touch the reality behind the absurdity while taking this into consideration.

3. Utterance reflecting the screwy personal relationship

In the course of the narrator's climbing the building, his acquaintances give him encouragement like "Shithead." and "Asshole." Here is established an obvious conflict between expressions of encouragement and those of poignancy, or an irony reflecting the social fact that people show no much concern with each other, indifference instead, even between acquaintances in the capitalist society. The same contrast lies also in sentences 35 "Better than a kick in the crotch.", 36. "Better than a poke in the eye with a sharp stick.", 37. "Better than a slap in the belly with a wet fish." and 38. "Better than a thump on the back with a stone."

They care about nothing but money or the valuables, which can find solid evidences in sentences 65 "My acquaintances moved among the fallen knights, collecting rings, wallets, pocket watches, ladies' favors." and 78 "My acquaintances were debating the question, which of them would get my apartment?" Sentences 39 "Won't he make a splash when he falls, now?" and 40 "I hope to be here to see it. Dip my handkerchief in the blood." tell us the naked coldness between one and the other. They play it to the extreme at the very moment when their acquaintance is confronted with peril or even death.

We may come to a safe conclusion that the masses below whom the narrator calls "my acquaintances" are thoroughly savage and aggressive blood-suckers who greedily wait for the fall of the climber to rob him, to get his apartment, to see if he makes a splash when he falls and to dip their handkerchiefs in his blood as they did to the ones who have fallen before. Hence, the panorama of the contemporary mass society of that certain age and of the present capitalist system can be penetrated clearly here via Barthelme's focuses on the narrator or the artist who tries in vain to escape from the society and system.

\section{Narrative Perspective}

A short story usually concentrates on a single incident and portrays a single character or a few characters. In nature, a story is indeed a narration, composed of such essential elements as the narrator, the plot, the setting, the theme and the character.

1. Usage of "I"

The Glass Mountain is characteristic of the first-person narration, beginning with "I was trying to climb the glass mountain." to tell us what was happening to the narrator. "I" inside the story presents himself as the narrator, the main character and also a participant, unfolding in front of us readers a more convincing picture of incidents as the story is told by "I" personally.

The perspective of using the first person gives us an impression of Barthelme's efforts to connect the story with the reality. But this, at the same time, forms a contrast between the story and the reality. Does anyone in the real life climb a glass mountain for a so-called symbol? As a matter of fact, the glass mountain is not a real mountain but a modern skyscraper in New York. Does anyone like "I" exist in the real society? Based on the two questions in mind, we can easily feel the symbolic, ironical and metaphorical senses of the fiction.

2. Collage

Barthelme's stories typically avoid traditional plot structures, relying instead on a steady accumulation of seemingly-unrelated detail, i.e. the discontinuity in narration. By subverting the reader's expectations through constant non sequiturs, Barthelme creates a hopelessly fragmented verbal collage. The Glass Mountain is no exception.

Throughout the story, the climbing incident is interwoven with the fragments of the fairy tale. It is the seemingly-unrelated detail that makes the story sound absurd. The collage form of writing here produces a grotesque mixture of scattered bits without a center or a logical line, symbolic of the mixed or messy cultural order because of anarchy. This writing technique reflects the disorder of human minds at that time and in that society when and where American people felt uncertain or even skeptical about capitalism, life, values, morality and the like.

3. The sequence arrangement of citations

There are used altogether five citations in the story, i.e. sentences $56,66,71,80$ and 87 , among which three $(56,66$, $87)$ are famous sayings by renowned people in the real material world while the other two $(71,80)$ are from a dictionary or a book. The former group (i.e. Sentences 56,66 and 87 ) are inserted into the story totally abruptly and seemingly at random, deepening the story's fragmentation and furthering its absurdity. Anton Ehrenzweig is a philosopher and a professor in University of Houston, the same school which Donald Barthelme once studied in. To cite somebody real 
and near helps draw the story nearer to the reality. The occurrence of the name reminds us readers of Barthelme's being drafted into the Korean War in 1953 when he was still a student in University of Houston.

M. Pompidou is the president in France from 1969 to 1974, that is to say, The Glass Mountain was written within Pompidou's presidency. By means of this association we are aware of the purposeful selection made by Barthelme. In this respect, we could not deny that reality does indeed lie behind the absurdity. Following the two citations, sentences 71 and 80 are presented related to conventions, turning to a dictionary or a book for reliable explanative support, which implies the right attitude towards literature creation.

The last citation is from John Masefield, the laureate poet in Britain. "In some centuries, his [man's] imagination has made life an intense practice of all the lovelier energies." indicates the significant and long-term role of imagination in human life. Considering the arrangement from a professor to a president and last to a poet, we may realize the meaningful transition of perspective in terms of themes from the existing secular life to politics and eventually to art. In other words, the story is originated from life, reflexive to certain social system but resorting to art in the end. The glass mountain is symbolic of the highly-developed industry and the narrator was trying to climb the mountain to disenchant a certain convention because of his dissatisfaction with the present social situation but at last the symbol on the top turned out to be still the cliche, no more free choice to make but only to rely on imagination, the artistic means to make the artist's voice heard.

\section{CONCLUSION}

The glass mountain itself is significant in the story as a symbolic representation of achievement and the isolation of an individual from the masses of the working class in industrialized capitalist American society. Here Donald Barthelme rejects traditional chronology, plot, character, time, space, grammar, syntax, as well as the traditional distinctions between fact and fiction. Adequate analyses show that he doesn't intend to offer an orderly reflection of, or comment upon a stable, external world through the fiction, but to unfold in front of us the real picture of people's chaotic and absurd ideological world as well as that of the existing social contradictions. "The Glass Mountain," however, envisions a mountain removed from nature as a modern high office building, an edifice that embodies the degradation of an emerging American society in the 1960s that is in search of "the American Dream" through material or monetary gains, but in the end encounters disillusion at the sacrifice of failure.

\section{ApPendix The Glass Mountain By Donald BARThelme}

1. I was trying to climb the glass mountain.

2. The glass mountain stands at the corner of Thirteenth Street and Eighth Avenue.

3. I had attained the lower slope.

4. People were looking up at me.

5. I was new in the neighborhood.

6. Nevertheless I had acquaintances.

7. I had strapped climbing irons to my feet and each hand grasped sturdy plumber's friend.

8. I was 200 feet up.

9. The wind was bitter.

10. My acquaintances had gathered at the bottom of the mountain to offer encouragement.

11. "Shithead."

12. "Asshole."

13. Everyone in the city knows about the glass mountain.

14. People who live here tell stories about it.

15. It is pointed out to visitors.

16. Touching the side of the mountain, one feels coolness.

17. Peering into the mountain, one sees sparkling blue-white depths.

18. The mountain towers over that part of Eighth Avenue like some splendid, immense office building.

19. The top of the mountain vanishes into the clouds, or on cloudless days, into the sun.

20. I unstuck the righthand plumber's friend leaving the lefthand one in place.

21. Then I stretched out and reattached the righthand one a little higher up, after which I inched my legs into new positions.

22. The gain was minimal, not an arm's length.

23. My acquaintances continued to comment.

24. "Dumb motherfucker."

25. I was new in the neighborhood.

26. In the streets were many people with disturbed eyes.

27. Look for yourself.

28. In the streets were hundreds of young people shooting up in doorways, behind parked cars.

29. Older people walked dogs. 
30. The sidewalks were full of dogshit in brilliant colors: ocher, umber, Mars yellow, sienna, viridian, ivory black, rose madder.

31. And someone had been apprehended cutting down trees, a row of elms broken-backed among the VWs and Valiants.

32. Done with a power saw, beyond a doubt.

33. I was new in the neighborhood yet I had accumulated acquaintances.

34. My acquaintances passed a brown bottle from hand to hand.

35. "Better than a kick in the crotch."

36. "Better than a poke in the eye with a sharp stick."

37. "Better than a slap in the belly with a wet fish."

38. "Better than a thump on the back with a stone."

39. "Won't he make a splash when he falls, now?"

40. "I hope to be here to see it. Dip my handkerchief in the blood."

41. "Fart-faced fool."

42. I unstuck the lefthand plumber's friend leaving the righthand one in place.

43. And reached out.

44. To climb the glass mountain, one first requires a good reason.

45. No one has ever climbed the mountain on behalf of science, or in search of celebrity, or because the mountain was a challenge.

46. Those are not good reasons.

47. But good reasons exist.

48. At the top of the mountain there is a castle of pure gold, and in a room in the castle tower sits...

49. My acquaintances were shouting at me.

50. "Ten bucks you bust your ass in the next four minutes!"

51. ... beautiful enchanted symbol.

52. I unstuck the righthand plumber's friend leaving the lefthand one in place.

53. And reached out.

54. It was cold there at 206 feet and when I looked down I was not encouraged.

55. A heap of corpses both of horses and riders ringed the bottom of the mountain, many dying men groaning there.

56. "A weakening of the libidinous interest in reality has recently come to a close." (Anton Ehrenzweig)

57. A few questions thronged into my mind.

58. Does one climb a glass mountain, at considerable personal discomfort, simply to disenchant a symbol?

59. Do today's stronger egos still need symbols?

60. I decided that the answer to these questions was "yes."

61. Otherwise what was I doing there, 206 feet above the power-sawed elms, whose white meat I could see from my height?

62. The best way to fail to climb the mountain is to be a knight in full armor--one whose horse's hoofs strike fiery sparks from the sides of the mountain.

63. The following-named knights had failed to climb the mountain and were groaning in the heap: Sir Giles Guilford, Sir Henry Lovell, Sir Albert Denny, Sir Nicholas Vaux, Sir Patrick Grifford, Sir Gisbourne Gower, Sir Thomas Grey, Sir Peter Coleville, Sir John Blunt, Sir Richard Vernon, Sir Walter Willoughby, Sir Stephen Spear, Sir Clarence Vaughan, Sir Hubert Ratcliffe, Sir James Tyrrel, Sir Walter Herbert, Sir Robert Brakenbury, Sir Lionel Beaufort, and many others.

64. My acquaintances moved among the fallen knights.

65. My acquaintances moved among the fallen knights, collecting rings, wallets, pocket watches, ladies' favors.

66. "Calm reigns in the country, thanks to the confident wisdom of everyone." (M. Pompidou)

67. The golden castle is guarded by a lean-headed eagle with blazing rubies for eyes.

68. I unstuck the lefthand plumber's friend, wondering if--

69. My acquaintances were prising out the gold teeth of not-yet dead knights.

70. In the streets were people concealing their calm behind a façade of vague dread.

71. "The conventional symbol (such as the nightingale, often associated with melancholy), even though it is recognized only through agreement, is not a sign (like the traffic light) because, again, it presumably arouses deep feelings and is regarded as possessing properties beyond what the eye alone sees." (A Dictionary of Literary Terms)

72. A number of nightingales with traffic lights tied to their legs flew past me.

73. A knight in pale pink armor appeared above me.

74. He sank, his armor making tiny shrieking sounds against the glass.

75. He gave me a sideways glance as he passed me.

76. He uttered the word "Muerte"

77. I unstuck the righthand plumber's friend.

78. My acquaintances were debating the question, which of them would get my apartment? 
79. I reviewed the conventional means of attaining the castle.

80. The conventional means of attaining the castle are as follows: "The eagle dug its sharp claws into the tender flesh of the youth, but he bore the pain without a sound, and seized the bird's two feet with his hands. The creature in terror lifted him high up into the air and began to circle the castle. The youth held on bravely. He saw the glittering palace, which by the pale rays of the moon looked like a dim lamp; and he saw the windows and balconies of the castle tower. Drawing a small knife from his belt, he cut off both the eagle's feet. The bird rose up in the air with a yelp, and the youth dropped lightly onto a broad balcony. At the same moment a door opened, and he saw a courtyard filled with flowers and trees, and there, the beautiful enchanted princess." (The Yellow Fairy Book)

81. I was afraid.

82. I had forgotten the Bandaids.

83. When the eagle dug its sharp claws into my tender flesh--

84. Should I go back for the Bandaids?

85. But if I went back for the Bandaids I would have to endure the contempt of my acquaintances.

86. I resolved to proceed without the Bandaids.

87. "In some centuries, his [man's] imagination has made life an intense practice of all the lovelier energies." (John Masefield)

88. The eagle dug its sharp claws into my tender flesh.

89. But I bore the pain without a sound, and seized the bird's two feet with my hands.

90. The plumber's friends remained in place, standing at right angles to the side of the mountain.

91. The creature in terror lifted me high in the air and began to circle the castle.

92. I held on bravely.

93. I saw the glittering palace, which by the pale rays of the moon looked like a dim lamp; and I saw the windows and balconies of the castle tower.

94. Drawing a small knife from my belt, I cut off both the eagle's feet.

95. The bird rose up in the air with a yelp, and I dropped lightly onto a broad balcony.

96. At the same moment a door opened, and I saw a courtyard filled with flowers and trees, and there, the beautiful enchanted symbol.

97. I approached the symbol, with its layers of meaning, but when I touched it, it changed into only a beautiful princess.

98. I threw the beautiful princess headfirst down the mountain to my acquaintances.

99. Who could be relied upon to deal with her.

100. Nor are eagles plausible, not at all, not for a moment.

\section{REFERENCES}

[1] Araz,T. (1999). Coming to Terms with a Postmodern World: Donald Barthelme's Dissident Stance, In Snow White and Others. Istanbul: Cantay Kitabevi.

[2] Fügen ToksÖz. (2011). Postmodern World, Postmodern Relationships: The Artist and Society Relationship in Barthelme's Fiction. journal.dogus.edu.tr/index.php/duj/article/download/247/261 (accessed 26/7/2011).

[3] Gerhard Hoffmann. (2005). From Modernism to Postmodernism: Concepts and Strategies of Postmodern American Fiction. Editions Rodopi B.V., Amsterdam-New York.

[4] Jian-Hua, Yu. (2010). Short Stories in English--- A Reading Course. Beijing: Higher Education Press.

[5] McCaffery, L. (1982). The Metafictional Muse: The Works of Robert Coover, Donald Barthelme, and William H. Gass. Pittsburgh: University of Pittsburgh Press.

Xiaohua Wen, Ninggang Jiangxi, China, 25/09/1976, master of arts in English Language and Literature, Central South University, Changsha, China, 2003, comparative study of English and Chinese

She has been working in Hangzhou Normal University since 2004, teaching a range of English courses like English Reading, English Grammar, Integrated English and An Introduction to Britain and America etc. She has published several Chinese articles and is currently interested in English teaching and research and comparative study of English and Chinese. 